\title{
Histone-Lysine N-Methyltransferase H3 Lysine-79 Specific
}

National Cancer Institute

\section{Source}

National Cancer Institute. Histone-Lysine N-Methyltransferase H3 Lysine-79 Specific. NCI Thesaurus. Code C73703.

Histone-lysine N-methyltransferase, H3 lysine-79 specific (1379 aa, 185 kDa) is encoded by the human DOT $1 \mathrm{~L}$ gene. This soluble, nuclear protein may play a role in activating or repressing transcription by RNA polymerase II. 